\title{
PERAN PESANTREN DALAM WACANA DAN PEMBERDAYAAN MASYARAKAT MADANI
}

\author{
Wahyuddin Halim \\ Universitas Islam NegeriAlauddin Makassar \\ JalanH.M. Yasin Limpo Nomor36,Gowa,92113,Sulawesi Selatan \\ E-mail:wahyuddin.halim@uin-alauddin.ac.id
}

\begin{tabular}{c|c|c}
\hline Received: & Revised: & Approved: \\
$17 / 08 / 2017$ & $28 / 11 / 2017$ & $20 / 12 / 2017$ \\
\hline
\end{tabular}

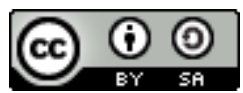

Peran Pesantren dalam Wacana dan Pemberdayaan Masyarakat Madani is licensed under a Creative Commons Attribution-ShareAlike 4.0 International License.

\begin{abstract}
Abstrak
Di Indonesia, wacana tentang civil society atau masyarakat sipil bermula pada sekitar akhir dekade 1990-an. Hal itu merupakan respons terhadap wacana yang sama yang juga sedang hangat diperbincangkan secara global sejak sekitar pertengahan dekade yang sama. Namun demikian, di Indonesia pada awalnya wacana bahkan perdebatan tentang civil society terbatas pada kalangan intelektual, akademisi kampus dan aktivis lembaga swadaya masyarakat. Dalam berbagai diskursus akademik dan nonakademik tentang civil society, isu pertama berkaitan dengan padanan atau terjemahan mana yang tepat bagi konsep itu untuk konteks Indonesia. Ada pihak yang memilih mempertahankan istilah bahasa Inggris civil society, ada juga yang menawarkan terjemahan 'masyarakat sipil', 'masyarakat kewargaan', 'masyarakat warga', dan 'masyarakat madani'. Medan diskursif kedua berkaitan dengan pemahaman dan pemaknaan terhadap konsep civil society dan kompatibilitas penerapannya dalam konteks masyarakat Indonesia. Artikel ini menyoroti secara khusus perbedaan pandangan antara kalangan 'tradisionalis' dan 'modernis' Muslim di Indonesia dalam
\end{abstract}


memahami dan memaknai konsep civil socity. Secara khusus, artikel ini berupaya mengeksplorasi eksistensi pesantren sebagai institusi pendidikan Islam tertua dan terbesar di Indonesia dalam memerankan diri sebagai salah satu elemen civil society yang, pada gilirannya, dapat berkontribusi signifikan dalam upaya transformasi dan pemberdayaan masyarakat sipil sebagai bagian dari proses konsolidasi demokrasi di Indonesia yang masih terus berlangsung.

Kata Kunci: Civil society, Pemberdayaan, Muslim tradisionalis, dan Pesantren.

\begin{abstract}
In Indonesia, the discourse on civil society began in around the end of the1990s. It is a response to the same discourse that was also being warmly discussed globally since around the middle of the same decade. However, in Indonesia at first discourse even the debate about civil society is limited to intellectuals, campus academics, and activists of non-governmental organizations. In academic and nonacademic discourses on civil society, the first issue relates to which equivalent or translation is most appropriate for that concept for the Indonesian context. Some people choose to retain the English term civil society, some others offer Indonesia translations such as 'masyarakat sipil', 'masyarakat kewargaan', 'masyarakat warga', dan 'masyarakat madani'. The second discursive field is concerned with the understanding of and giving meaning to the conept of civil society and the compatibility of its application in the context of Indonesian society. This article highlights the different views between Muslim 'traditionalists' and 'modernists' in Indonesia in understanding and giving new meanings to the concept of civil socity. In particular, this article seeks to explore the existence of pesantren as the oldest and largest Islamic educational institution in Indonesia in acting as one of the elements of civil society that, in turn, can contribute significantly to the transformation and empowerment of civil society as part of the ongoing process of democratic consolidation in Indonesia.
\end{abstract}

Keywords: Civil society, Empowerment, Traditionalist Muslim, and Pesantren

\title{
A. Pendahuluan
}

Wacana tentang civil society baru menyeruak di kalangan intelektual, akademisi dan aktivis lembaga-lembaga swadaya masyarakat pada sekitar akhir dekade tahun 1990-an. Di masa-masa selanjutnya, perbincangan bahkan perdebatan tentang civil socity 
juga melibatkan kalangan yang selama ini di kenal dekat atau identik dengan kelompok politisi, birokrat dan militer. Selama masa tersebut di atas hingga sekitar pertengahan tahun 2000-an, ungkapan-ungkapan atau jargon-jargon yang sering mencuat dalam diskursus tentang demokrasi khususnya, dan transformasi sosial-politik di Indonesia umumnya, pasca-Reformasi antara lain: "pembentukan masyarakat madani", "memperkuat masyarakat sipil", dan "menuju masyarakat madani". Ungkapan-ungkapan tersebut mulai menggantikan jargon lama yang sudah demikian klise selama masa pemerintahan Orde Baru seperti "pembangunan nasional", atau "mewujudkan masyarakat adil dan makmur berdasarkan Pancasila".

Berdasarkan hasil penelitian PPIM-UIN Jakarta bertajuk "Potensi Civil Society di Kalangan Muslim Perkotaan" pada sekitar akhir 1999, dari segi lokasi, sosialisasi gagasan tentang civil society masih lebih banyak berlangsung di Jakarta dan Yogyakarta. Sementara itu, di kota-kota lain yang menjadi sampel penelitian ini: Medan, Padang, Bandung, Surabaya dan Makassar, substansi konsep civil society, termasuk sejarah perkembangannya dalam setting kebudayaan Barat dan bagaimana ini dimanifestasikan dalam kehidupan sehari-hari, masih merupakan sesuatu yang belum jelas benar. Terdapat banyak variasi dalam pemahaman para tokoh yang diwawancarai di kota-kota tersebut terakhir tentang konsep civil society, yang merefleksikan perbedaan tingkat keterlibatan mereka masing-masing dengan isu tersebut. ${ }^{1}$

Namun demikian, sebagai sebuah terminologi sosial-politik, civil society tampaknya demikian cepat termasyarakatkan. Paling tidak, masih mengacu kepada temuan PPIM, ada tiga faktor yang mendukung cepatnya proses pemasyarakatan itu. Pertama, maraknya penggunaan istilah civil society oleh kalangan intelektual, aktivis LSM dan kalangan pemerintah dalam berbagai forum seperti seminar, workshop, talkshow dan lain-lain. Kedua, banyaknya publikasi dalam bentuk buku, jurnal, majalah dan surat kabar mengenai civil society dan berbagai padanannya dalam bahasa Indonesia. Dan ketiga, iklim kebebasan berbicara dan mengeluarkan pendapat yang semakin

${ }^{1}$ Hendro Prasetyo dan Ali Munhanif, eds.,Islam dan Civil Society: Pandangan Muslim Indonesia, (Jakarta: Gramedia Pustaka Utama bekerjasama dengan PPIM-IAIN Jakarta, 2002). 
terbuka pasca keruntuhan rezim otoriter Orde Baru. Yang terakhir ini memungkinkan masyarakat berani mengulas tema-tema yang sebelumnya ditabukan.

Artikel ini mengulas diskursus dan kontestasi pemaknaan civil society dalam masyarakat Muslim di Indonesia, khususnya di kalangan Muslim tradisionalis dan modernis. Juga diula implikasi afiliasi keagamaan masing-masing terhadap pemaknaan dan pemosisian diri masing-masing pihak dalam wacana tentang civil socity. Selanjutnya, dengan menggunakan pendekatan penelitian sejarah dan antropologi, artikel ini berupaya menelaah secara khusus bagaimana dan sejauh mana komunitas pesantren di Indonesia terlibat dalam diskursus tentang civil society dan peranannya dalam pemberdayaan masyarakat yang menunjang terwujudnya civil society di Indonesia.

\section{B. Gagasan Civil Society: Soal Penerjemahan dan Pemaknaan}

Dalam berbagai wacana tentang civil society di Indonesia, terdapat sejumlah perbedaan pendapat sekitar terjemahan yang tepat atas istilah itu atau padanannya dalam bahasa Indonesia. Seperti akan diulas berikutnya, perbedaan terjemahan dan pilihan padanan istilah civil society dalam bahasa Indonesia merefleksikan juga perbedaan pemaknaan dan si pember makna atas substansi istilah tersebut. Mansour Faqih, seorang aktivis LSM, misalnya, lebih suka menerjemahkan civil society dengan "masyarakat sipil". Lembaga Etika Atmajaya menerjemahkannya dengan "masyarakat warga". Frans Magnis Suseno dan Ryaas Rasyid memilih menggunakan istilah "masyarakat kewargaan" sebagai padanan civil society. ${ }^{2}$

Sementara itu, jika kategorisasi Muslim tradsionalis dan Muslim modernis bisa digunakan, yang secara populer dikaitkan dengan berturut Nahdlatul Ulama dan Muhammadiyah, terdapat juga pemaknaan yang berbeda antara kedua kalangan tersebut terhadap gagasan civil society. Muhammad AS Hikam, misalnya, tokoh yang dipandang merepresentasikan pandangan kalangan Muslim tradisional, cenderung tetap menggunakan istilah civil society tanpa mencari padanannya dalam bahasa Indonesia. Kalaupun harus diterjemahkan, Hikam memilih menggunakan istilah "masyarakat

\footnotetext{
${ }^{2}$ Prasetyo dan Munhanif, eds., Islam dan Civil Society.
} 
sipil". Di pihak lain, tokoh utama Islam modernis seperti Nurcholish Madjid dan M. Dawam Rahardjo menemukan istilah "masyarakat madani" sebagai padanan yang paling tepat bagi istilah civil society. ${ }^{3}$

Dari sejumlah upaya pemaknaan di atas, yang lebih menarik ustru adalah enyataanbahwa perbeaan wacana tentang civil society di kalanga nintelktual Muslim Indonesia, belakangan, lebih banyak mencerminkan perbedaan pemahaman yang mengemuka antara kalangan tradisionalis dan modernis atas istilah yang sedang dibicarakan, yaitu antara istilah civil society yang digunakan oleh kalangan Muslim tradisionalis dan istilah "masyarakat madani" yang ditawarkan oleh kalangan Muslim modernis. Dibandingkan dengan istilah-istilah yang disebutkan di atas, kedua istilah yang disebut terakhir itulah yang paling banyak digunakan dalam berbagai seminar dan publikasi tentang civil society di Indonesia selama ini.

Penggunaan istilah civil society secara konsisten oleh kalangan tradisionalis tampaknya mengacu pada kenyataan bahwa istilah tersebut lahir dari pengalaman sosial, politik, dan budaya Barat. Karena itu, daripada berupaya mencari-cari padanannya dalam tradisi Islam, adalah lebih baik menggunakan istilah itu dalam maknanya yang asal, yaitu sebagai lawan dari negara. Kalangan ini mengkritik kalangan modernis yang mereduksi istilah civil society dengan menyepadankannya dengan idealisasi masyarakat Madinah yang dibangun oleh Nabi MuhammadSAW di masa lalu. Padahal, menurut mereka, bangunan masyarakat Madinah sama sekali berbeda dengan kandungan istilah civil society. Di pihak lain, kalangan modernis berargumen bahwa "madani" yang merupakan derivasi dari kata "tamaddun", yang berarti peradaban (civilization) memiliki makna yang identik dengan civil society. Oleh karena itu, kalangan ini merasa lebih tepat menggunakan istilah "masyaraka madani".

\section{Masyarakat Sipil: Masyarakat versus Negara (Pandangan Kalangan Muslim Tradisionalis)}

Sulit dipungkiri bahwa, dalam konteks Indonesia, adlah kalangan Muslim tradisionalis, yang terutama diwakili oleh NU, yang lebih dahulu bersentuhan dan memasuaraatkan gagasan civil

\footnotetext{
${ }^{3}$ Prasetyo dan Munhanif, eds., Islam dan Civil Society.
} 
society. Hal ini dimunkinkan oleh paling tidak tiga faktor. Pertama, intelektual-intelektual muda yang berasal dari kalangan tradisionalis, misalnya Hikam yang sudah disebut di atas, tampaknya lebih dahulu tanggap terhadap perlunya memasyarakatkan gagasan civil society di Indonesia dalam rangka menciptakan masyarakat yang kuat dan mandiri vis-a-vis kekuasaan otoriter Orde Baru. ${ }^{4} K e d u a$, gagasan dari kelompok intelektual muda ini kemudian mendapat respons positif dari para aktivis lembaga kajian dan LSM dari kalangan tradisionalis, seperti Lembaga Kajian Islam dan Sosial (LKiS), Pusat Pengembangan Pesantren dan Masyarakat (P3M) dan Lembaga Kajian dan Pengembangan Sumberdaya Manusia (Lakspesdam) PB$\mathrm{NU}$, yang bergerak daam bidang pengembangan masyarakat hingga lapisan akar rumput di pedesaan. Dan ketiga, kalangan ini, selama masa pemerintahan Orde Baru, memiliki hubungan yang kurang lebih antagonistik dan traumatis dengan negara. Dalam situasi seperti itu, bisa dimengerti jika NU lebih reseptif terhadap gagasan civil society yang tampaknya bisa mereka gunakan sebagai medium penyeimbang antara masyarakat dan (atau bahkan perlawanan terhadap) negara.

Berkaitan dengan faktor di atas, bisa dimengerti kalau berkaitan dengan upaya mewujudkan demokrasi, kalangan tradisionalis pernah memposisikan negara sebagai "musuh" atau setidaknya sebagai entitas yang harus dilawan oleh "masyarakat sipil". Dalam pengalaman kalangan tradisionalis berhadapan dengan rezim Orde Baru, negaralah yang paling potensial melakukan pengebirian dan penindasan terhadap hak-hak rakyat.

Pada kenyataanya, gagasan civil society yang lahir dari rahim kesejarahan masyarakat Barat juga mengacu kepada pengalaman pahit mereka di bawah cengkeraman otoritarianisme dan totalitarianisme, baik oleh raja, bangsawan maupun kaum borjuis. Tidak mengherankan, ketika gagasan tentang civil society mulai mengemuka dalam diskursus sosial-politik di Indonesia, terdapat kesan umum bahwa civil society adalah lawan abadi negara, khususnya militerisme. Dengan kata lain, konsep-konsep awal tentang civil society sangat kental nuansa politiknya. Selain itu, civil society sering diidentikkan dengan gerakan-

${ }^{4}$ Muhammad AS Hikam, Islam, Demokratisasi, dan Pemberdayaan Civil Society, (Jakarta: Erlangga, 2000). 
gerakan prodemokrasi. Lebih jauh, gerakan-gerakan prodemokrasi dipandang sebagai prasyarat terpenting bagi pembentukan civil society. Tragisnya, gerakan prodemokrasi hampir selalu diasosiasikan dengan gerakan-gerakan oposisi terhadap pemerintah yang represif dan diktatoris. Sebagai akibatnya, suatu gerakan baru baru dapat disebut prodemorasi jika selalu berseberangan secara tegas dan konsisten dengan kekuasaan politik yang mapan. Guiseppe Di Palma yang dikutip Azra, berargumen bahwa civil society adalah bagian organik sistem demokrasi, yang secara definisi, berada dalam posisi perlawanan (oppositional) terhadap rezim-rezim absolutis dan bahwa civil society adalah musuh alamiah otokrasi, kediktatoran, dan bentukbentuk lain kekuasaan sewenang-wenang. ${ }^{5}$ Sekali lagi, karena setuju dengan alur argumen seperti ini, kalangan tradisionalis memilih tetap menggunakan istilah civil society daripada padanan lainnya dalam bahasa Indonesia dan konteks masyarakat Muslim.

\section{Masyarakat Madani: Negara sebagai Mitra Masyarakat (Pandangan Kalangan Muslim Modernis)}

Pilihan istilah "masyarakat madani" oleh kalangan modernis secara jelas memberikan warna lain sekaligus pemaknaan yang berbeda terhadap gagasancivil society. Kalangan modernis memandang negara secara positif, dalam arti tidak sebagai lawan, tetapi sebagai mitra yang dapat diajak bekerja sama membangun "masyarakat madani". Argumen utama kalangan ini, dengan kemitraan sama dan sejajar, demokrasi dapat dibangun.

Dalam beberapa hal, masyarakat madani yang digagas oleh kalangan modernis tidak terlalu jauh berbeda dengan konsep civil society, yakni berintikan demokrasi dan kedaulatan rakyat. Namun, kalau konsep civil society melulu berbicara dalam tataran dan paradigma politik, konsep masyarakat madani mengandung juga unsur keagamaan. Yang penting dicatat, pandangan positif kalangan modernis terhadap negara dalam konteks civil society juga mengacu kepada pengalaman historis kelompok ini, yang memiliki hubungan cukup harmonis dengan pemegang kekuasaan selama

${ }^{5}$ Azyumardi Azra, Menuju Masyarakat Madani: Gagasan, Fakta, dan Tantangan (Jakarta: Remaja Rosdakarya, 1999),viii. 
Orde Baru. Dengan kata lain, kalangan modernis selama ini tidak pernah mengalami pengalaman setragis rekan tradisionalis mereka vis-a-vis rezim Orde Baru, malah kadang-kadang menjadi bagian dari rezim tersebut. Pada kenyataannya, mereka lebih bisa menemukan identifikasi wawasan dan pengalaman sosio-politik mereka dengan gagasan masyarakat madani daripada istilah civil society. Jika penggunaan civil society cenderung sarat dengan gagasan perlawanan masyarakat "sipil" terhadap negara (atau militerisme, khususnya), maka istilah "masyarakat madani" kedengarannya lebih netral dan menekankan pada perlunya pembentukan masyarakat berkeadaban di mana tanpa negara gagasan itu menjadi mustahil diwujudkan.

\section{E. Masyarakat Madani atau Masyarakat Madinah?}

Istilah 'masyarakat madani' ---yang awalnya dipopulerkan oleh Muhammad Naquib Al-Attas kemudian di Indonesia oleh Anwar Ibrahim dan Nurcholish Madjid - sesungguhnya merupakan terjemahan dari kosa kata bahasa Arab, 'mujtama' al-madani'. Secara epistemologis, istilah yang disebut terakhir memiliki dua arti: pertama, "masyarakat kota", karena madani adalah turunan dari kata Arab 'madinah' yang berarti 'kota'. Kedua, "masyarakat yang berperadaban", karena madani adalah juga derivasi dari kata tamaddun atau madaniyyah yang berarti "peradaban". Padanan kata itu dalam bahasa Inggris adalah civility atau civilization). Dengan makna ini, masyarakat madani dalam beberapa hal identik dengan unsur penting civil society, yaitu masyarakat yang menjunjung tinggi nilainilai peradaban.

Secara historis, masyarakat madani adalah komunitas Muslim pertama di kota Madinah yang dipimpin langsung oleh Rasulullah saw. dan diikuti oleh keempat Khulafa al-Rasyidin (para pemimpin yang mendapatkan petunjuk). Menurut Nurcholish Madjid, masyarakat yang dibangun pada zaman Rasul tersebut identik dengan civil society, karena secara sosio-kultural mengandung substansi keadaban (civility). ${ }^{6}$ Madjid melihat bahwa civility mengandung makna toleransi, kesediaan menerima pribadi-pribadi untuk menerima berbagai

\footnotetext{
${ }^{6}$ Nurcholish Madjid, Cita-Cita Politik Islam Era Reformasi, (Jakarta: Paramadina, 1999).
} 
macam pandangan politik yang berbeda, juga kesediaan menerima pandangan yang sangat penting bahwa "tidak ada jawaban yang paling benar tentang suatu masalah". ${ }^{7}$

Upaya banyak kalangan modernis meruju pada komunitas zaman Nabi itu tampaknya cukup berlsan. Sebab kecanggiahan masyarakat yan pernah dibangun Nabi itu juga masih bisa dirunut jejaknya melaui sebuah paiagam tertulis yang disebut dengan Piagam Madinah (mitsaqul madinah). Inilah dokumen penting yang membuktikan betapa sangat majunya masyarakat yang dibangun kala itu, di samping juga memberikan penegasan mengenai kejelasan hukum dan konsitutisi sebuah masyarakat.

Sebagaimana terbaca dalam teks, piaham madinah menatuhr kehidpan sosial-politik penduduk Madinah secara lebih luas. Ada dua nilai dasar yang tertuang dalam Piagam Madinah kala itu. Pertama, prinsip kesederajatan dan keadilan (al-musawah wa al-'adalah). Kedua, inklusivisme atau keterbukaan. Kedua prinsip itu lalu dijabarkan dan ditanamkan ke dalam bentuk beberapa nilai universal, seperti konsistensi (i'tidal), keseimbangan (tawazun), moderasi (tawasul) dan toleransi (tasamuh). Oleh karena itu, dalam negeri Madinah saat itu, walaupun penduduknya majemuk, baik dalam arti agama, ras, suku maupun golongan, kedudukan mereka sama, masing-masing memiliki kebebasan untuk memeluk agama dan melaksanakan aktivitas dalam bidang sosial dan ekonomi. Setiap pihak mempunyai kebebebasan yang sama untuk membela Madinah sebagai tempat tinggal mereka.

Mungkin ada yang tertarik untuk bertanya, bagaimana Rasulullah saw. mampu membangun satu masyarakat modern di tengan padang gersang dan dalam sebuah lingkungan yang dicitrakan tak beradab itu? Salah satu jawabannya, Madina dapat tercipta menjadi kota peradaban hanya setelah Rasulullah saw melakukan reformasi dan transformasi internal yang berdimensi akidah, akhlak dan syari'ah pada pada setiap individu. Oleh karena itu, iman dan moralitas menjadi pijakan dasar Piagam Madinah, selain aktivitas sosio-politik yang egaliter dan berkeadilan. Semua prinsip dan nilai di atas menjadi fondasi bagi semua aspek kehidupan masyarakat, baik aspek politik, ekonomi maupun hukum di masa itu yang

\footnotetext{
${ }^{7}$ Nurcholish Madjid, Cita-Cita Politik Islam.
} 
memungkinkan civil society yang diidealkan itu pernah terwujud secara empiris di muka bumi, bukan sekedar sebagai impian.

\section{F. Strategi Pemberdayaan Civil Society: Peran Pesantren}

Pesantren dianggap sebagai institusi pendidikan Islam tertua di Indonesia yang berawal di Jawa. Beberapa ilmuwan mengklaim bahwa pesantren telah menjadi pusat pembelajaran Islam tradisional yang paling penting di Indonesia. ${ }^{8}$ Meskipun keberadaannya dapat ditelusuri pada periode paling awal Islamisasi di nusantara, Dhofier berpendapat bahwa pesantren yang kita kenal sekarang baru muncul pada awal abad kesembilan belas. ${ }^{9}$ Dia menggambarkan lima elemen utama sistem pendidikan pesantren: (1) akomodasi untuk siswa (pondok); (2) masjid dimana siswa paling tepat belajar; (3) teks Islam klasik dalam bahasa Arab sebagai sumber belajar utama; (4) santri, darimana istilah pesantren, tempat santri, diturunkan; dan (5) kiyai (guru besar, juga ulama). ${ }^{10}$

Salah satu ciri penting pesantren adalah metode pembelajaran Islam yang dikenal dengan bandongan di Jawa (atau mangaji kitta dalam bahasa Bugis, artinya, 'belajar dengan atau dari buku'). Dalam pedagogi model ini, kiyai membaca sebuah buku teks Islam klasik, menjelaskan isi dan gagasannya, dan menerjemahkan maknanya ke dalam bahasa daerah kepada para santri yang duduk di sekelilingnya, yang memegang buku teks yang sama, mendengarkan dan membuat catatan tentang makna teks tersebut. Di banyak bagian negeri Muslim, khususnya di Timur Tengah, bentuk pembelajaran Islam ini disebut halaqah (dari bahasa Arab, artinya 'lingkaran'). Secara umum, pesantren memainkan peran penting yang serupa dengan apa yang Azra, Afrianty dan Hefner sebutkan berkaitan dengan institusi pendidikan Islam di dunia Muslim secara umum: (1) mentransmisikan

${ }^{8}$ Azyumardi Azra, Islam Nusantara, Jaringan Global dan Lokal, (Bandung: Mizan; Steenbrink 1986); Karel A. Steenbrink, Pesantren, Madrasah, Sekolah: Pendidikan Islam dalam Kurun Moderen, (Jakarta: Lembaga Penelitian, Pendidikan dan Penerangan Ekonomi dan Sosial (LP3ES), 1986.

${ }^{9}$ Zamakhsyari Dhofier, The Pesantren Tradition: the Role of the Kyai in the Maintenance of Traditional Islam in Java, (Tempe AZ: Program for Southeast Asian Studies, Arizona State University),15-16.

${ }^{10}$ Dhofier, The Pesantren Tradition. 
pengetahuan agama; (2) menjaga tradisi Islam secara keseluruhan, dan (3) menyediakan pusat pelatihan dan reproduksi sosial para ulama. ${ }^{11}$

Pesantren, seperti diilustrasikan oleh Marzuki Wahid, "adalah sebuah wacana yang hidup. Selama ada kemauan, perbincangan tentang pesantren akan senantiasa menarik, segar, aktual, dan --perlu dicatat-tidak mudah". ${ }^{12}$ Salah satu hal paling menarik dari pesantren, menurut Marzuki lebih lanjut, adalah bahwa sekalipun ia bersifat multidimensional, ia sangat percaya diri dan penuh daya pertahanan-diri (self-defensive) dalam menghadapi tantangan di luar dirinya. ${ }^{13}$ Sebagai contoh, walau pesantren dikenal sebagai lembaga pendidikan yang mungkin paling tradisional di Indonesia, tapi berkat watak tradisionalismenya itu, tidak dapat dipungkiri, ia justru paling kuat bertahan hidup dalam menghadapi gempuran modernitas dunia yang memandang tradisi sebagai masalah. Tidak jarang, masyarakat justru memandang pesantren sebagai pilihan alternatif terbaik dalam menghadapi tantangan modernitas.

Sementara itu, kepemimpinan pesantren yang selama ini dianggap bercorak tradisional dipandang tidak kompatibel dengan nilai-nilai demokrasi modern. Hal itu karena kepemimpinan pesantren menggunakan keunggulan karismatik kiyai-nya yang, justru karena itu, dinilai feodalistik. Namun, melalu basis kitab kuning yang dimilikinya, tampak juga betapa tinggi tingkat kemandirian pesantren dalam relasi sosial yang lebih luas dari dirinya, melebihi lembaga yang menyebut dirinya independen sekalipun. ${ }^{14}$ Lebih jauh, sekalipun kiyai menjadi bagian dari lapisan elit sosial keagamaan, tapi etos populisme dankedekatannya dengan lapisan masyarakat bawah masih sulit ditandingi oleh lembaga-lembaga yang secara eskplisit berlabelkan "rakyat" atau "masyarakat". Sementara itu, khususnya di Jawa, secara eksklusif pesantren pada umumnya hanya dimiliki oleh pribadi seseorang atau kelompok kiyai-ulama (dan karena itu

${ }^{11}$ Azyumardi Azra, Dina Afrianty dan Robert W. Hefner, "Pesantren and Madrasa: Muslim Schools and National Ideals in Indonesia", dalam Robert W. Hefner dan Muhammad Q. Zaman (eds.), Schooling Islam: the Culture and Politics of Modern Muslim Education, (Princeton NJ: Princeton University Press, 2007),174.

${ }^{12}$ Marzuki Wahid, dkk. Pesantren Masa Depan: Wacana Pemberdayaan dan Transformasi Pesantren, (Jakarta: Pustaka Hidayah, 1999),145.

${ }^{13}$ Marzuki Wahid dkk, Pesantren Masa Depan,145-6.

${ }^{14}$ Dhofier, The Pesantren Tradition. 
dinilai sejenis nepotisme). ${ }^{15}$ Di luar Pulau Jawa, seperti di Sulawesi Selatan, pesantren umumnya bukan dimiliki oleh seorang kiyai. Memang seorang kiyai atau anrégurutta adalah pihak pertama yang mensponsori atau memulai pendidikan suatu pesanten. Akan tetapi, tanah di mana bangunan pesantren didirikan, juga bangunan beserta seluruh alat-alat belajar biasanya disumbangkan oleh pemerintah dan pengusaha lokal. Untuk pengelolaan pesantren, dibentuk suatu yayasan yang pengurusnya terdiri atas ulama, pejabat, pengusaha dan tokoh-tokoh masyarakat setempat.

Pada kenyataanya, menurut penulis, melalui amal usahanya di bidang pendidikan dan dakwah, fungsi sosial pesantren tidak kalah efektifnya dengan lembaga-lembaga milik masyarakat dan diorientasikan khusus untuk kegiatan-kegiatan sosial.Dengan mencermati kemandirian dan basis massa-bawah pesantren, Martin van Bruinessen, sarjana Belanda yang banyak meneliti tentang kehidupan pesantren, mengamati bahwa dalam tubuh pesantren terkandung potensi besar bagi terwujudnya civil society sebagai pilar demorkasi di Indonesia. ${ }^{16}$ Namun demikian, menurut van Bruinessen, sekalipun pola hubungan demokratis itu terjadi dalam gerak dinamis pesantren, demokrasi desa tetap tidak bisa diharapkan dari pesantren. ${ }^{17}$ Hal itu karena, menurut dia, kiyai-ulama di pesantren adalah raja dan tokoh kharismatik, sementara kharisma dan demokrasi tidak dapat menyatu.

Fajrul Falaakh justru melihat pada sisi yang lain dari kharisma kiyai ini. Menurut dia, secara eksternal, melalui para kiyai-ulamanya, pesantren dapat memainkan fungsi mediasi dan fasilitatif dalam rangka koneksi dan asosiasi antara masyarakat dan penguasa atau pihak-pihak lain di luar masyarakat. ${ }^{18}$ Fungsi mediator seperti ini pula yang diamati Clifford Geertz dalam studinya tentang peran kiyai

${ }^{15}$ Dhofier, The Pesantren Tradition.

${ }^{16}$ Martin van Bruinessen,Kitab Kuning, Pesantren dan Tarekat (Edisi Revisi; Yogyakarta: Gading Publishing, 2012).

${ }^{17}$ Bruinessen, Kitab Kuning.

${ }^{18}$ Muhammad Fajrul Falaakh, "Nahdlatul Ulama and Civil Society in Indonesia", in Mitsuo Nakamura, Omar Farouk Bajunid, dan Sharon Shiddique, eds. Islam and Civil Society in Southeast Asia, (Singapore: ISEAS, 2001). 
sebagai "makelar budaya" (cultural broker). ${ }^{19}$ Sementara itu, Hiroko Horikoshi menunjukkan posisi dan kekuatan kiyai sebagai sumber perubahan sosial bukan saja pada masyarakat pesantren tetapi juga pada masyarakat di sekitarnya. ${ }^{20}$ Fungsi koneksi dan asosiasi yang bebas, mandiri dan bertanggung-jawab, menurut Michael Walzer, merupakan elemen penting civil society. ${ }^{21}$

Secara umum, fungsi mediasi dan fasilitatif ini, mengutip Falaakh lagi, dapat diperluas ke dalam skala yang besar, mengingat jaringan ulama dan pesantren merupakan infrastruktur komunikasi sosial yang selama ini terbukti efektif di pedesaan. ${ }^{22}$ Seperti umumnya diketahui, mediasi semacam itu merupakan juga salah satu mekanisme dalam demokrasi. Wahid meyakini bahwa karena watak otentiknya yang cenderung menolak pemusatan (sentralisasi), bahkan merupakan komunitas yang secara sangat signifikan terdesentralisasi dan karena lokasinya pada umumnya di tengah-tengah masyarakat (pedesaan), maka pesantren sangat berpotensi secara efektif memainkan peran pemberdayaan (empowerment) dan transformasi masyarakat. ${ }^{23}$

Lebih penting lagi, menurut penulis, seperti halnya Nabi Muhammad saw. melakukan reformasi dan transformasi individual yang berdimensi akidah, syari'ah dan akhlak terhadap masyarakat Madinah untuk membangun iman dan moralitas sebagai pijakan bagi pembumian Piagam Madinah, maka pesantren juga bisa memainkan peran yang sama dalam konteks masyarakat Indonesia. Dengan kata lain, agar civil society bisa terwujud, diperlukan pijakan atau landasan imaniah dan komitmen moral dari tiap warganya untuk mewujudkan kehidupan yang demokratis, egaliter, toleran, inklusif dan menghargai pluralitas. Dalam bahasa Walzer, tanpa ketertarikan dan tanggungjawab antarindividu, tidak ada "kebebasan dan keadilan". ${ }^{24}$ Sementara itu, agar landasan iman dan komitmen moral bisa terbangun, sebuah upaya reformatif dan transformatif terhadap tiap individu dalam civil

${ }^{19}$ Clifford Geertz, "The Javanese Kijaji: The Changing Role of a Cultural Broker", Comparative Studies in Society and History, 2 (2) (1960).

${ }^{20}$ Hiroko Horikoshi, Kiai dan Perubahan Sosial, terj. Umar Basalim dan Andy Muarly Sunrawa, (Jakarta: P3M, 1987).

${ }^{21}$ Michael Walzer, "The Idea of Civil Society," Dissent (Spring), (1991).

${ }^{22}$ Falaakh, "Nahdlatul Ulama".

${ }^{23}$ Wahid dkk., Pesantren Masa Depan.

${ }^{24}$ Walzer, "The Idea of Civil Society,"304. 
society perlu dilakukan, dan pesantren bisa mengambil peran-peran seperti itu.

Patut dicatat bahwa kajian tentang pesantren pernah menjadi bidang kajian yang cukup pesat perkembangannya, khususnya selama dekade 1980-an dan 1990-an. Untuk menyebut beberapa di antara studi terpenting tentang pesantre, misalnya, kajian Azra, Bruinessen dan Steenbrink yang menggarisbawahi peran penting pesantren dalam transmisi pengetahuan dan nilai-nilai Islam di aras lokal. ${ }^{25}$ Sementara itu, Horikoshi, Lukens-Bull dan Rahardjo mencermati kekuatan adaptif pesantren dalam proses perubahan sosial dan modernitas. ${ }^{26}$ Kiprah pesantren dalam pembangunan ekonomi ditelaah oleh Budiwiranto, Permani, Suaedy dan Sulistyo, Suprayogo, dan Turmudi. ${ }^{27}$ Kontribusi pesantren dalam pendidikan gender dan penyemaian nasionalisme juga menjadi kajian beberapa sarjana. ${ }^{28}$ Demikian juga peran yang dimainkan oleh pesantren dalam penguatan nilai-nilai kewarganegaraan dan masyarakat sipil, seperti pluralisme. ${ }^{29}$ Studi yang sama dari Suaedy dan Sulistyo dan Suprayogo juga meneroka keterlibatan komunitas pesantren

${ }^{25}$ Azyumardi Azra, Islam Nusantara, Jaringan Global dan Lokal, (Bandung: Mizan, 2002); Martin van Bruinessen, Kitab Kuning; dan Karel A, Steenbrink, Pesantren, Madrasah, Sekolah: Pendidikan Islam dalam Kurun Moderen, (Jakarta: Lembaga Penelitian, Pendidikan dan Penerangan Ekonomi dan Sosial (LP3ES), 1986).

${ }^{26}$ Hiroko Horikoshi, Kyai dan Perubahan Sosial; Ronald Lukens-Bull, A Peaceful Jihad: Negotiating Identity and Modernity in Muslim Java, (New York: Palgrave Macmillan, 2005); dan M. Dawam Rahardjo, (ed.),Pesantren dan Pembaharuan, (Jakarta: Lembaga Penelitian Pendidikan dan Penerangan Ekonomi dan Sosial (LP3ES), 1988).

27 Bambang Budiwiranto, "Pesantren and Participatory Development in Indonesia", (Tesis MA, Australian National University, Canberra, 2007); Risti Permani, "The Presence of Religious Organisations, Religious Attendance and Earnings: Evidence from Indonesia", Journal of Socio-Economics 40 (3), 2011: 247-58; Ahmad Suaedy dan Hermawan Sulistyo, Kiyai dan Demokrasi: Sebuah Potret Pandangan tentang Pluralisme, Toleransi, Persamaan, Negara, Pemilu, dan Partai Politik, (Jakarta: P3M Jakarta and Asia Foundation, 2000); Imam Suprayogo, Kiyai dan Politik: Membaca Citra Politik Kiyai, (Malang: UIN Malang Press, 2007); dan Endang Turmudi, Struggling for the Umma: Changing Leadership Roles of Kiai in Jombang, East Java. Canberra: ANU E-Press, 2006).

${ }^{28}$ Sri Purwaningsih, Kiai dan Keadilan Gender, (Semarang: Walisongo Press, 2007); Ali Mashcan Moesa, Nasionalisme Kiai: Konstruksi Sosial Berbasis Agama, (Surabaya: IAIN Sunan Ampel Press \& LKiS Yogyakarta, 2007); dan Achmad Zaini, Kyai Haji Abdul Wahid Hasyim: His Contribution to Muslim Educational Reform and Indonesian Nationalism during the Twentieth Century, (Yogyakarta: Indonesian Academic Society XXI, 1998).

${ }_{29}$ Andre Feillard, Gus Dur, NU, dan Masyarakat Sipil, (Yogyakarta: LKiS and Pustaka Pelajar, 1994), dan Florian Pohl, "Religious Education and Secularization: 
dalam dinamika politik di Indonesia. ${ }^{30}$ Studi penulis sendiri, menunjukkan peran sentral pesantren dalam transformasi otoritas dan identitas keagamaan. ${ }^{31}$

\section{G. Pesantren As'adiyah: Contoh Kasus Peran Pesantren dalam Penguatan Civil Society}

Pada bagian ini, penulis akan mengulas satu contoh kasus di mana satu pesantren, yaitu Pesantren As'adiyah, dapat menjadi salah satu institusi yang telah dan sedang memainkan peran yang turut memperkuat civil society dalam konteks lokal. Peran itu dimainkan dalam berbagai program-program pendidikan, keagamaan dan sosial-budaya seperti akan dijelaskan di bawah. Sebelumnya, sebuah deskripsi singkat tentang profil pesantren ini kiranya perlu diberikan.

Pesantren As'adiyah adalah salah satu lembaga pendidikan tertua dan paling berpengaruh di Sulawesi Selatan sejak paruh kedua abad kedua puluh. Pesantren yang semula bernama AlMadrasah al-'Arabiyah al-Islamiyah (MAI) ini didirikan oleh AGH Muhammad As'ad al-Bugis (1907-1952)(yang di kalangan santrinya dan masyarakat Muslim di Wajo lebih dikenal dengan sebutan Anrégurutta Puang Aji Sade' atau Gurutta Sade') $)^{32}$ pada 1930 di

Indonesia's Pesantren Tradition and Civil Society, (Disertasi Doktor, Temple University, Philadelphia, 2007).

${ }^{30}$ Suaedy dan Sulistyo, Kiyai dan Demokrasi; Suprayogo, Kiyai dan Politik.

31 Wahyuddin Halim, "As'adiyah Traditions: the Construction and Reproduction of Religious Authority in Contemporary South Sulawesi", Disertasi Doktor, the Australian National University, Canberra, 2015. Lihat juga Bahaking Rama, Jejak Pembaharuan Pendidikan Pesantren: Kajian Pesantren As'adiyah Sengkang Sulawesi Selatan, (Jakarta: Parodatama Wiragemilang, 2003).

${ }^{32}$ Di Sulawesi Selatan, khususnya dalam masyarakat suku Bugis, 'gurutta' dan 'anrégurutta' adalah dua istilah populer yang merujuk kepada sosok ulama atau kiyai di Jawa. Sedikit berbeda dengan makna asli kata 'guru' dari bahasa Sanskerta, yang terutama terkait dengan fungsi religius dan spiritual seorang guru, di Sulawesi Selatan istilah 'guru' digunakan untuk setiap orang yang mengajarkan sesuatu. Ini termasuk guru di sekolah (B. guru sikola), di kelas belajar membaca Alquran (B. guru mangaji) dan bela diri (B. guru sila'). Meskipun demikian, hanya seorang guru agama yang berkualitas dan ulama yang disebut 'gurutta' dalam masyarakat Muslim Bugis (yang berarti 'guru kita'). Ulama dengan otoritas dan pengaruh keagamaan tertinggi disebut 'anrégurutta', yang diberi arti khusus sebagai 'guru besar kita'. Di bawah tingkat anrégurutta adalah gurutta. Dalam penulisannya, anrégurutta disingkat menjadi AG. Jika seorang anreguru sudah menunaikan ibadah haji, maka singkatannya adalah AGH (anrégurutta haji). Istilah yang lebih belakangan muncul, 'ustadz' (dari bahasa 
Sengkang, Wajo, Sulawesi Selatan. Sekitar dua dekade sebelum pendirian As'adiyah, di Sulawesi Selatan sudah ada beberapa lembaga pendidikan Islam tradisional dalam bentuk pengajaran baca-hafal Al-Qur'an dan bahasa Arab serta pengajian pesantren, misalnya Pesantren Pulau Salemo di Pangkajene dan Kepulauan (1910-1944) yang sempat melahirkan sejumlah ulama tradisional yang pada gilirannya menyelenggarkan pengajaran agama secara tradisional di daerah-daerah asal mereka di Sulawesi Selatan setelah meninggalkan Pulau Salemo. ${ }^{33}$ Di Wajo sendiri, sebelum kedatangan Anrégurutta Sade', sudah ada beberapa ulama yang mengadakan pengajian-pengajian dalam bentuk halaqah, baik pengajian Al-Qur'an maupun kitab-kitab agama yang tertulis dalam bahasa Arab. ${ }^{34}$ Namun demikian, sistem pembelajaran agama yang digunakan oleh para ulama yang disebutkan di atas masih sangat sederhana, baik dalam hal metode maupun instrumen pembelajarannya.

Dibanding dengan lembaga-lembaga pendidikan Islam yang menda-huluinya, Pesantren As'adiyah relatif lebih berhasil melahirkan generasi baru ulama tradisional di Sulawesi Selatan pada abad kedua puluh. Dalam penelitian penulis, beberapa faktor berikut ini mungkin dapat menjelaskan keberhasilan tersebut. Pertama, lembaga pendidikan As'adiyah tidak saja mengajarkan bidang-bidang klasik pengetahuan Islam dengan metode halaqi (atau mangaji tudang dan mangaji kitta dalam bahasa Bugis) tetapi juga mendirikan lembaga-lembaga pendidikan modern yang menerapkan sistem klasikal atau madrasi seperti halnya lembaga pendidikan yang didirikan oleh pemerintah kolonial Belanda dan organisasi Muslim modernis seperti Muhammadiyah pada kurun waktu yang sama.

Arab) juga digunakan untuk guru agama dan mubalig yang tingkatan keilmuan dan pengaruh keagamaannya di bawah level gurutta. Ahmad menyebutkan tiga kriteria utama seorang anrégurutta: sudah mencapai tingkat tertinggi dalam pengetahuan Islam ('ilm), praktik ('amal) dan moralitas (akhlaq). Lihat, A. Kadir Ahmad, Ulama Bugis, (Makassar: Indobis Publishing, 2008),177.

${ }^{33}$ Abu Hamid, "Sistem Pendidikan Madrasah dan Pesantren di Sulawesi Selatan", dalam Taufik Abdullah dan Mattulada, eds.,Agama dan Perubahan Sosial, (Jakarta: Rajawali Press, 1983);lihat juga Mustari Bosra, Tuang Guru, Anrong Guru dan Daeng Guru: Gerakan Islam di Sulawesi Selatan 1914-1942, (Makassar: Lagaligo Press, 2008).

${ }^{34}$ M. Jufri Dolong, "Peranan Ulama dalam Masyarakat di Kabupaten Wajo", (Skripsi Sarjana, Fakultas Adab IAIN Alauddin Ujung Pandang, 1982). 
Belakangan As'adiyah juga mendirikan sekolah-sekolah umum mulai tingkat TK sampai perguruan tinggi di mana diajarkan ilmu-ilmu agama dan ilmu-ilmu umum sesuai kurikulum nasional. ${ }^{35}$

Kedua, sejak berdirinya, selain mengelola berbagai tingkatan lembaga pendidikan seperti disebutkan di atas, As'adiyah juga menyelenggarakan program khusus Tahfidz Al-Qur'an melalui lembaga yang disebut Majelis al-Qurra wa al-Huffadz dan pengkaderan ulama melalui program pengkaderan ulama, Al-Ma'had al-'Aly li al-Dirasat al-Islamiyyah li al-As'adiyah yang hingga hari ini masih merupakan program utama yayasan ini. Program yang disebut pertama telah melahirkan banyak sekali hafidz (penghafal) yang telah berkiprah di berbagai tempat dan dalam berbagai bidang profesional, baik sebagai ulama, imam, imam besar maupun sebagai hafidz dan qari'ah profesional dalam berbagai tingkatan kompetisi kecakapan AlQur'an (MTQ), baik level nasional maupun internasional. Sementara itu, program pengkaderan ulama telah melahirkan ulama-ulama terkemuka yang kini membaktikan diri di sejumlah daerah di Sulawesi Selatan dan provinsi lainnya seperti Kalimantan Timur, Sulawesi Tenggara, Maluku, Papua, dan Riau, baik sebagai ulama (Kiyai atau Kiyai Muda/KM) dengan tugas-tugas dakwah dan pembinaan umat lainnya maupun sebagai pegawai urusan agama dan profesi lainnya. ${ }^{36}$

Ketiga, sejak awal berdirinya, Pesantren As'adiyah juga telah menjadikan kegiatan dakwah keagamaan sebagai program utamanya. Anrégurutta Sade' dan murid-murid generasi pertamanya adalah ulama-ulama yang sangat berpengaruh pada abad kedua puluh karena keterlibatan total mereka dalam bidang dakwah dan pengajaran agama di daerah masing-masing. ${ }^{37}$ Menurut Bruinessen, Anrégurutta Sade' bahkan dipandang sebagai salah satu tokoh terpenting dalam gerakan reformasi dan purifikasi Islam di Sulawesi Selatan pada abad kedua puluh, ${ }^{38}$ di samping tokoh-tokoh dari

\footnotetext{
${ }^{35}$ Wahyuddin Halim, "As'adiyah Traditions".

${ }^{36}$ Wahyuddin Halim, "As'adiyah Traditions".

${ }^{37}$ Wahyuddin Halim, "As'adiyah Traditions".

${ }^{38}$ Martin van Bruinessen, "Muhammad As'ad Bugis (Wajo, South Sulawesi,
} Indonesia, 1907-1953)", dalam Dictionnaire Biographique des Savants et Grande Figures du Monde Musulman Périphérique, du XIXe siécle à nos jours, Fasc. no 2, (Paris: CNRSEHESS, 1998). 
organisasi Muhammadiyah yang sudah membuka cabang di daerah ini sejak 1926. ${ }^{39}$ Seperti diteliti oleh Hatta Walinga, sejak masa awal kedatangan Anrégurutta Sade' dari Mekah ke Sengkang pada 1928, ulama keturunan Bugis yang lahir di Mekah pada 1907 ini sudah membentuk semacam korps mubalig untuk menggalakkan program dakwah khususnya di kalangan masyarakat Wajo yang diayakini telah mempraktekkan ajaran Islam yang jauh dari otentik dan tidak merujuk kepada sumber-sumber tekstual yang otoritatif..$^{40}$

Terlepas dari beberapa faktor yang disebutkan di atas, Anrégurutta Sade' menjadi demikian menonjol karena dia dan pesantren serta madrasah yang dia dirikan telah melahirkan beberapa generasi ulama yang paling berpengaruh di Sulawesi Selatan sejak paruh kedua abad kedua puluh. Lebih penting lagi, para ulama didikan Anrégurutta Sade' ini berperan penting dalam proses transformasi otoritas keagamaan di kawasan ini sejak itu. ${ }^{41}$ Berawal dari Anrégurutta Sade', jaringan atau generalogi baru ulama di Sulawesi Selatan abad kedua puluh terbentuk. Menurut Syamsuddin Arief, ulama-ulama produk As'adiyah ini, lewat lembaga-lembaga pendidikan Islam yang mereka dirikan, belakangan mampu melahirkan pula generasi baru ulama di wilayah yang mencakup wilayahyang cukup luas, khusus di kawasan timur Indonesia. ${ }^{42}$

Di antara ulama terpenting yang pernah berguru pada atau dibina di madrasah dan pesantren Anrégurutta Sade' adalah AGH Abdurrahman Ambo Dalle (1900-1996), pendiri pesantren DDI di Mangkoso, Pare-pare dan Pinrang; AGH Daud Ismail (1908-2006) pendiri pesantren Yastrib, Soppeng; AGH M. Yunus Maratan (19061986), pelanjut kepemimpinan Perguruan As'adiyah Sengkang, AGH Abd. Kadir Khalid, pendiri Pesanten MDIA Taqwa, Makassar; AGH Abdul Muin Yusuf (1920-2004), pendiri Pesantren Al-Urwatul, Sidrap; AGH Muhammad Abduh Pabbaja (1918-2009), pendiri Pesantren Al-Furqan, Pare-Pare; AGH Marzuki Hasan (1917-2006), pendiri

${ }^{39}$ Lihat Sahabuddin Saleh, dkk. Selintas Sejarah Muhammadiyah Kabupaten Wajo, (Sengkang: t.p., 1991).

40 Muh. Hatta Walinga, "Kiyai Haji Muhammad As'ad hidup dan perjuangannya", (Skripsi Sarjana Fak. Adab IAIN Alauddin, Makassar, 1981).

${ }^{41}$ Wahyuddin Halim, "As'adiyah Traditions".

${ }^{42}$ Syamsuddin Arief, "Jaringan Pesantren Sulawesi Selatan" (Disertasi Doktor UIN Syarif Hidayatullah, Jakarta, 2007). 
Pesantren Darul Falah Maccopa, Maros, AGH Muh. Hasyim, pendiri Madrasah Fakhriyah, Belopa, Luwu; dan AGH Burhanuddin, pendiri Pesantren DDI Polmas (Lihat Diagram 1). ${ }^{43}$

Jika kita menggunakan kerangka peran lembaga pendidikan Islam secara umum di dunia Islam seperti disebutkan oleh Azra dkk di atas, maka Pesantren As'adiyah telah dan masih menjalankan ketiga fungsi tersebut: mentransmisi pengetahuan agama dari pusat Islam di Timur Tengah ke tengah-tengah masyarakat; turut menyemaikan dan menjaga tradisi Islam ahlussunnah wal jama'ah secara konsisten, dan menjadi pusat pelatihan dan reproduksi para calon-calon ulama yang akan diterjunkan ke tengah-tengah masyarakat. ${ }^{44} \mathrm{Al}-$ Madrasah al-'Arabiyyah al-Islamiyyah (MAI) yang didirikan oleh Anrégurutta Sade' dan belakangan menjadi Madrasah As'adiyah (1953), kemudian Pesantren As'adiyah, menurut Mattulada, merupakan pusat pengajaran Islam terpenting di Sulawesi Selatan di paruh kedua abad kedua puluh. Murid-murid madrasah ini berasal dari beberapa kabupaten di Sulawesi Selatan seperti Bone, Soppeng, Sidenreng, Sinjai, dan Bulukumba, maupun dari provinsi lain seperti Kalimantan Timur. ${ }^{45}$

Dimulai dari Anrégurutta Sade', ulama-ulama yang lahir dari MAI, berkat otoritas mereka di bidang pengetahuan agama Islam dan pengaruh mereka di tengah-tengah masyarakat, mereka dapat menjadi salah satu kelompok elit dalam masyarakat di Sulawesi Selatan yang memiliki posisi dan pengaruh yang kurang lebih setara dengan elit tradisional yang terdiri atas para bangsawan, kesatria dan orang-orang kaya. ${ }^{46}$ Anrégurutta Sade', begitu juga ulama pelanjut dia dalam memimpin MAI dan Madrasah As'adiyah, memiliki karisma, keteguhan dan keteladanan moral yang menjadikan mereka disegani oleh seluruh kalangan masyarakat, termasuk oleh para elit tradisional, khususnya para bangsawan yang selama masa pra-Kemerdekaan RI, mendapat privilese traditional menduduki jabatan-jabatan penting

\footnotetext{
${ }^{43}$ Lihat Syamsuddin Arief "Jaringan Pesantren".

${ }^{44}$ Lihat Azra, Afrianty dan Hefner, "Pesantren and Madrasa",174.

${ }^{45}$ Mattulada, "Islam di Sulawesi Selatan," dalam Taufik Abdullah, ed. Agama dan Perubahan Sosial, (Jakarta: Rajawali Press, 1983),271-2.

${ }^{46}$ Abd. Azis Al-Bone, "Peranan Kyai di Sulawesi Selatan (Studi Kasus KHM As'ad di Sengkang Wajo)," (Jakarta: Pusat Penelitian dan Pengkajian, Pengembangan Pesantren dan Masyarakat (P3M) Pesantren Ciganjur, 1987).
} 
dalam kerajaan. Selama masa rezim otoriter Orde Baru di mana dalam setiap pemilu Golkar selalu menjadi partai pemerintah dan menang, beberapa ulama dari Pesantren As'adiyah menjadi kelompok penyeimbang, misalnya karena memilih jadi pengurus Partai Persatuan Pembangunan (PPP). Karena karisma dan pengaruh kuat mereka yang berpotensi diikuti secara politis oleh masyarakat, tidak jarang para ulama ini ditekan bahkan diinterogasi oleh pemerintah agar mereka meninggalkan PPP dan menjadi anggota Golkar.

Lepas dari peran 'oposisi' seperti disebutkan di atas, yang lebih sering terjadi adalah bahwa para elit tradisional ini berkonsultasi dengan para ulama pesantren berkaitan dengan masalah-masalah dalam kerajaan. Tidak jarang juga, para ulama ini memberikan masukan dan nasehat menurut perspektif agama kepada penguasa lokal dalam beragam media dan bentuk, sebuah peran yang sudah dilihat dalam konteks kiyai di Jawa sebagai 'makelar budaya' (cultural broker). ${ }^{47}$ Dalam posisi seperti itu, para ulama ini menjadi salah satu elemen penting dalam masyarakat Wajo yang di masa lalu, yakni sebelum bergabung mejadi bagian Negara Kesatuan Republik Indonesia pada 1949, terkenal sebagai "kerajaan demokratis" atau "kerajaan aristokratik demokratis". Kerajaan Wajo layak mendapat status seperti itu karena, menurut sejumlah sarjana, khususnya selama abad kelima belas hingga awal abad keenam belas, Wajotelah menerapan sejumlah prinsip demokrasi (modern) -seperti dikenal saat-- ini dalam sistem pemerintahan dan kehidupan masyarakatnya. ${ }^{48}$

Yang juga perlu dicatat, sebelum 1930-an praktis belum ada lembaga pendidikan Islam formal di Sulawesi Selatan yang menerima jumlah siswa dalam jumlah yang relatif besar seperti MAI. Sebelum periode ini, yang banyak ditemukan adalah lembaga-lembaga pengajian Alquran dalam bentuk non-klasikal yang mengambil tempat

${ }^{47}$ Tentang dinamika hubungan antara elit agama dan elit tradisional di Sulawesi Selatan, lihat Wahyuddin Halim, "Arung, Topanrita dan Anregurutta dalam Masyarakat Bugis Abad XX”, Jurnal Al-Ulum, vol 12, no. 2 (2012).

${ }^{48}$ Tentang Wajo sebagai kerajaan yang unik di Sulawesi Selatan, bahkan di Nusantara, karena mempraktikkan beberapa prinsip demokrasi dalam sistem kerajaan, lihat Wahyuddin Halim, "Eksplorasi atas Praktik dan Nilai-nilai Demokrasi dalam Kerajaan Wajo' Abad ke-15/16 dan Kompatibilitasnya dengan Sistem Demokrasi Modern", Jurnal Masyarakat dan Budaya, Vol. 18 No. 2 (2016). 
pembelajaran di musola, masjid dan rumah guru mengaji. Kelahiran MAI yang disusul dengan madrasah dan pesantren yang didirikan oleh alumni MAI di berbagai daerah di Sulawesi Selatan turut mengubah peta keagamaan di wilayah ini. Para alumni MAI menjadi generasi baru otoritas agama yang menjadi rujukan bagi masyarakat Muslim setempat dalam memahami dan mempraktikkan ajaran agama sesuai dengan tuntunan kitab suci dan kitab-kitab keagamaan standar yang tertulis dalam bahasa Arab. Bahkan, seperti penulis ulas di tempat lain, MAI dan berikutnya Pesantren As'adiyah berperan penting mentransformasi pemahaman dan praktik keislaman masyarakat Muslim serta mentransformasi makna dan institusi otoritas keagamaan (ulama) di Sulawesi Selatan hingga akhir abad kedua puluh. Sebelum MAI menghasilkan alumni dengan pengetahuan agama Islam yang luas dan dalam, yang selalu mengisi pos-pos penting dalam institusi agama sebagai bagian penting dari struktur kerajaan adalah mereka yang berasal dari kalangan bangsawan. Setelah MAI dan Pesantren As'adiyah menelurkan alumni, mereka inilah yang kemudian mulai mengisi pos-pos tersebut, yang di Sulawesi Selaan dikenal dengan istilah parewa sara' (perangkat Syariah), seperti jabatan khatib, imam, bilal dan modin.

Kehadiran kalangan terpelajar yang memiliki kesadaran tentang hak-hak dan tanggung jawabnya dalam konteks sosialpolitik setempat menjadi prasyarat atau elemen penting dalam civil society. Sejak masih berupa madrasah (MAI) hingga belakangan menjadi pesantren, Pesantren As'adiyah telah berkontribusi besar dalam menciptakan peluang bagi warga masyarakat dari berbagai kalangan dan status sosial untuk mengenyam pendidikan yang relatif murah, bahkan gratis, khususnya pendidikan agama. Selain itu, di masa-masa belakangan Pesantren As'adiyah juga meluaskan program pendidikannya hingga mencakup wilayah yan lebih luas lewat dua program dakwahnya. Pertama, penerbitan buku, jurnal dan majalan dalam tiga bahasa, Bugis, Indonesia dan Arab. Segmen pembaca terbitan-terbitan berkala As'adiyah ini termasuk kalangan perantau Bugis di Selawesi Tenggara, Kalimantan Timur serta Jambi dan Bengkulu. Kedua, pengiriman ratusan tim mubalig selama bulan Ramadan ke berbagai wilayah di Indonesia, khususnya di bagian timur, guna mengisi mimbar-mimbar dakwah selama bulan itu 
di masjid-masjid yang jamaahnya umumnya terdiri atas kalangan perantau Bugis dari daerah Wajo, Bone dan Soppeng. Program ini masih terus berlangsung hingga saat ini dan sudah pernah mencapai sekitar 600 mubalig yang terdiri atas minimal siswa MTs kelas tiga, siswa-siswi Madrasah Aliyah, mahasiswa Sekolah Tinggi Agama Islam As'adiyah (kini IAIA), dan mahasantri program pengkaderan ulama atau Ma'ahad 'Aly. ${ }^{4}$

Selain beberapa program di bidang pendidikan dan dakwah yang disebutkan di atas, peran Pesantren As'adiyah dalam pemberdayaan civil society dapat dilihat dalam program-program pemberdayaan sosial-ekonomi umat lewat, misalnya, Baitul Mal wat Tamwil (BMT) dan penyaluran zakat dan sadaqah untuk kalangan masyarakat miskin. Belakangan, beberapa alumni Pesantren As'adiyah mulai berkiprah bukan lagi pada jalur-jalur "tradisional" seperti menjadi imam, khatib, penyuluh agama, ulama, pegawai KUA dan sebagainya, tetapi menjadi saudagar yang berhasil di beberapa daerah perantauan orang-orang Bugis di Kalimantan Timur, Sumatera, Papua, Sulawesi Tenggara dan Sulawesi Barat. Selain ini, sejak era Reformasi 1998, beberapa alumni pesantren ini berhasil menduduki jabatan-jabatan politik, terutama sebagai anggota legislatif di tingkat provinsi dan daerah. Tentu saja, kiprah mereka di lembaga-lembaga sosial-politik ini sedikit banyak akan diwarnai atau diilhami oleh tradisi pesantren yang pernah mereka pelajari dan praktikkan selama masih menjadi santri.

\section{H. Simpulan}

Berdasarkan paparan dalam paragraf-paragraf di atas, terlihat bahwa gagasan dan idealisme civil society dalam konteks Islam di Indonesia hanya bisa terwujud jika dalam masyarakat terdapat kesadaran atas hak-hak individu, kemandirian relatif dari negara, kebebasan berpendapat dan mencipta, kesederajatan di depan hukum, dan ketulusan dalam bakti sosial. Dalam konteks masyarakat Indonesia yang religius, perwujudan civil society hanya mungkin terjadi jika terdapat pijakan normatif yang memberikan

${ }^{49}$ Tentang program ini lebih jauh, lihat Wahyuddin Halim, "As'adiyah Traditions", khususnya Bab VI. 
legalitas teologis atas gagasan yang diarak di kalangan masyarakat dari tingkatan akar rumput hingga kalangan elit.

Dalam konteks masyarakat Muslim di Indonesia, pesantren dapat turut berperan dalam menyemaikan nilai-nilai civil society yang disebutkan di atas dan menyediakan pijakan-pijakan normatif berdasarkan ajaran Islam yang menjadi anutan mayoritas penduduk Indonesia. Untuk membangun pijakan-pijakan normatif yang dimaksud, pertama-tama pesantren harus melakukan reformasi dan transformasi teologis dan ideologis secara internal, kemudian disusul dengan reformasi dan transformasi kehidupan masyarakat di luar pesantren.

Beberapa pengalaman praktis di lapangan telah membuktikan bahwa hanya setelah penyediaan pijakan-pijakan normatif berdasarkan doktrin keislaman lebih dahulu, barulah proyek-proyek "pembangunan", khususnya selama masa Orde Baru, dapat berhasil diimplementasikan dalam masyarakat Indonesia. Sebagai contoh, Andi F. Bakti menunjukkan efektivitas peran para ulama dalam memberikan pijakan normatif bagi program Keluarga Berencana (KB) sehingga program itu mencapai keberhasilan besar selama masa Orde Baru. ${ }^{50}$ Masdar F. Mas'udi membuktikan bahwa kesadaran tentang hak-hak reproduksi baru dapat dibangkitkan di kalangan perempuan di beberapa desa di Jawa dan Madura setelah melalui pelatihan-pelatihan intensif di beberapa pesantren di mana kitabkitab kuning dikaji dalam perspektif gender. ${ }^{51}$ Demikian juga, riset Halim menunjukkan bahwa pengaruh latar belakang pengetahuan keagamaan, selain latar belakang keluarga dan budaya, berpengaruh penting dalam membentuk perspektif dan sikap kaum Muslim di Sulawesi Selatan tentang relasi-relasi gender dalam masyarakat. ${ }^{52}$

Dengan menelaah Pesantren As'adiyah di Sengkang, Kabupaten Wajo, Sulawesi Selatan sebagai contoh kasus, terlihat bahwa pesantren dapat berkontribusi, baik langsung maupun tidak

${ }^{50}$ Andi Faisal Bakti, Communication and Family Planning in Islam in Indonesia: South Sulawesi Muslim Perceptions of a Global Development Program, (Leiden: INIS, 2004).

${ }^{51}$ Masdar F. Mas'udi, Islam dan Hak-hak Reproduksi Perempuan, (Bandung: Mizan, 1997).

${ }^{52}$ Wahyuddin Halim, Agama dan Issu Gender dalam Pembangunan: Perspektif Muslim Sulawesi Selatan, (Makassar: Alauddin Press, 2012). 
langsung, dalam penyemaian dan penguatan civil society. Membuka peluang bagi setiap warga untuk mengeyam pendidikan, walau masih terbatas pada pendidikan agama, kontribusi pertama dari sebuah pesantren dalam menyemaikan benih pembentukan suatu civil society, yaitu budaya literasi. Hal berikutnya adalah bahwa para ulama pesantren berhasil mewujudkan diri sebagai salah satu kelompok elit dalam masyarakat. Pada kenyataannya, mereka mampu memainkan peran pengimbang di tengah dominasi kalangan elit sosial lainnya, khususnya kalangan bangsawan, dalam proses-proses sosial-politik di tengah-tengah masyarakat. Beragam program dakwah pesantren juga turut berperan mengembangkan pengetahuan dan kesadaran keagamaan masyarakat Bugis, termasuk yang berada perantauan di berbagai wilayah di Indonesia, yang menunjang pembentukan civil society. Hal terakhir, selain dimensi kontributif lain yang tidak semuanya dapat diulas dalam artikel ini, adalah keterlibatan langsung sejumlah alumni pesantren dalam proses demokratisasi di Indonesia pasca-Reformasi, yaitu dengan menjadi pejabat di lembaga-lembaga pemerintahan, terutama di lembaga legislatif tetapi beberapa dari mereka juga sudah mulai menjejaki peluang di lembaga eksekutif, misalnya untuk menjadi kepala daerah[.]

\section{REFERENSI}

Abd. Kadir M.“Transformasi Kelekturan pada Pesantren As'adiyah Sengkang", dalam Abd. Azis Al-Bone, ed. Transformasi Kelekturan Pesantren di Sulawesi Selatan. Ujung Pandang: Balai Penelitian Kelekturan Keagamaan, 1994.

Abu Hamid. "Sistem Pendidikan Madrasah dan Pesantren di Sulawesi

Selatan." Dalam Agama dan Perubahan Sosial. Dalam T. Abdullah dan Mattulada, eds. Jakarta: Rajawali Press, 1983.

Ahmad,A. Kadir. Ulama Bugis. Makassar: Indobis Publishing, 2008.

Al-Bone, Abd. Azis. «Peranan Kyai di Sulawesi Selatan (Studi Kasus KHM As>ad di Sengkang Wajo).» Jakarta: Pusat Penelitian dan Pengkajian, Pengembangan Pesantren dan Masyarakat (UnitEP3M) Pesantren Ciganjur, 1987. 
Arief, Syamsuddin. "Jaringan Pesantren Sulawesi Selatan". Disertasi Doktor UIN Syarif Hidayatullah, Jakarta, 2007.

Azra, Azyumardi, Dina Afrianty dan Robert W. Hefner. "Pesantren and Madrasa: Muslim Schools and National Ideals in Indonesia". Dalam Robert W. Hefner dan Muhammad Q. Zaman, eds.Schooling Islam: the Culture and Politics of Modern Muslim Education. Princeton NJ: Princeton University Press, 2007.

Azra, Azyumardi. Islam Nusantara, Jaringan Global dan Lokal. Bandung: Mizan, 2002.

Azra, Azyumardi.Menuju Masyarakat Madani: Gagasan, Fakta, dan Tantangan. Jakarta: Remaja Rosdakarya, 1999.

Bakti, Andi Faisal. Communication and Family Planning in Islam in Indonesia: South Sulawesi Muslim Perceptions of a Global Development Program. Leiden: INIS, 2004.

Bosra, Mustari. Tuang Guru, Anrong Guru dan Daeng Guru: Gerakan Islam di Sulawesi Selatan 1914-1942. Makassar: Lagaligo Press, 2008.

Bruinessen, Martin van. "Muhammad As'ad Bugis (Wajo, South Sulawesi, Indonesia, 1907-1953)." Dalam Dictionnaire Biographique des Savants et Grande Figures du Monde Musulman Périphérique, du XIXe siécle à nos jours, Fasc. no 2. Paris: CNRSEHESS, 1998.

Bruinessen, Martin van. Kitab Kuning, Pesantren dan Tarekat. Edisi Revisi; Yogyakarta: Gading Publishing, 2012.

Budiwiranto, Bambang. "Pesantren and Participatory Development in Indonesia". Tesis MA, Australian National University, Canberra, 2007.

Dhofier, Zamakhsyari. The Pesantren Tradition: the Role of the Kyai in the Maintenance of Traditional Islam in Java. Tempe AZ: Program for Southeast Asian Studies, Arizona State University, 1999.

Dolong, M. Jufri. "Peranan Ulama dalam Masyarakat di Kabupaten Wajo". Skripsi Sarjana, Fakultas Adab IAIN Alauddin Ujung Pandang, 1982. 
Falaakh, Muhammad Fajrul. "Nahdlatul Ulama and Civil Society in Indonesia". Dalam Mitsuo Nakamura, Omar Farouk Bajunid, dan Sharon Shiddique, eds. Islam and Civil Society in Southeast Asia. Singapore: ISEAS, 2001.

Feillard, Andre. Gus Dur, NU, dan Masyarakat Sipil. Yogyakarta: LKiS and Pustaka Pelajar, 1994.

Geertz, Clifford. „The Javanese Kijaji: The Changing Role of a Cultural Broker". Comparative Studies in Society and History, 2(2), 1960: 228-249.

Halim, Wahyuddin. "Arung, Topanrita dan Anregurutta dalam Masyarakat Bugis Abad XX". Jurnal Al-Ulum12 (2), 2012: 317334.

Halim, Wahyuddin.Agama dan Issu Gender dalam Pembangunan: Perspektif Muslim Sulawesi Selatan. Makassar: Alauddin Press, 2012.

Halim, Wahyuddin. "As'adiyah Traditions: the Construction and Reproduction of Religious Authority in Contemporary South Sulawesi". Disertasi Doktor, the Australian National University, Canberra, 2015.

Halim, Wahyuddin. “Eksplorasi atas Praktik dan Nilai-nilai Demokrasi dalam Kerajaan Wajo' Abad ke-15/16 dan Kompatibilitasnya dengan Sistem Demokrasi Modern". Jurnal Masyarakat dan Budaya, 18 (2), 2016: 187-202.

Hamid, Abu. "Sistem Pendidikan Madrasah dan Pesantren di Sulawesi Selatan".Dalam Taufik Abdullah dan Mattulada, eds. Agama dan Perubahan Sosial. Jakarta: Rajawali Press, 1983.

Hikam, Muhammad AS.Islam, Demokratisasi, dan Pemberdayaan Civil Society. Jakarta: Erlangga, 2000.

Horikoshi, Hiroko. Kiai dan Perubahan Sosial. Terj. Umar Basalim dan Andy Muarly Sunrawa. Jakarta: P3M, 1987.

Lukens-Bull, Ronald. A Peaceful Jihad: Negotiating Identity and Modernity in Muslim Java. New York: Palgrave Macmillan, 2005

Madjid, Nurcholish. Cita-Cita Politik Islam era Reformasi. Jakarta: Paramadina, 1999. 
Mas'udi, Masdar F. Islam dan Hak-hak Reproduksi Perempuan. Bandung: Mizan, 1997.

Mattulada. «Islam di Sulawesi Selatan,» dalam Taufik Abdullah, ed. Agama dan Perubahan Sosial. Jakarta: Rajawali Press, 1983.

Moesa, Ali Mashcan.Nasionalisme Kiai: Konstruksi Sosial Berbasis Agama. Surabaya: IAIN Sunan Ampel Press \& LKiS Yogyakarta, 2007.

Nawir. "Sejarah Pesantren As'adiyah di Sengkang Kabupaten Wajo" Laporan Penelitian Sejarah dan Nilai Tradisional Sulawesi Selatan. Departemen Pendidikan da Kebudayaan, Direktorat Jenderal Kebudayaan Balai Kajian Sejarah dan Nilai Tradisional, Ujung Pandang, 1999/2000.

Permani, Risti. "The Presence of Religious Organisations, Religious Attendance and Earnings: Evidence from Indonesia". Journal of Socio-Economics 40 (3), 2011: 247-58.

Pohl, Florian. "Religious Education and Secularization: Indonesia's Pesantren Tradition and Civil Society. Disertasi Doktor, Temple University, Philadelphia, 2007.

Prasetyo, Hendro dan Ali Munhanif, dkk. Islam dan Civil Society: Pandangan Muslim Indonesia. Jakarta: Gramedia Pustaka Utama bekerjasama dengan PPIM-IAIN Jakarta, 2002.

Purwaningsih, Sri. Kiai dan Keadilan Gender. Semarang: Walisongo Press, 2007.

Rahardjo, M. Dawam, ed.Pesantren dan Pembaharuan. Jakarta: Lembaga Penelitian Pendidikan dan Penerangan Ekonomi dan Sosial (LP3ES), 1988.

Rama, Bahaking. Jejak Pembaharuan Pendidikan Pesantren: Kajian Pesantren As'adiyah Sengkang Sulawesi Selatan. Jakarta: Parodatama Wiragemilang, 2003.

Saleh, Sahabuddin, dkk. Selintas Sejarah Muhammadiyah Kabupaten Wajo. Sengkang: t.p., 1991.

Steenbrink, Karel A. Pesantren, Madrasah, Sekolah: Pendidikan Islam dalam Kurun Moderen. Jakarta: Lembaga Penelitian, Pendidikan dan Penerangan Ekonomi dan Sosial (LP3ES), 1986.

Suaedy, Ahmad dan Hermawan Sulistyo. Kiyai dan Demokrasi: Sebuah Potret Pandangan tentang Pluralisme, Toleransi, Persamaan, 
Negara, Pemilu, dan Partai Politik. Jakarta: P3M Jakarta and Asia Foundation, 2000.

Suprayogo, Imam.Kiyai dan Politik: Membaca Citra Politik Kiyai. Malang: UIN Malang Press, 2007.

Turmudi, Endang. Struggling for the Umma: Changing Leadership Roles of Kiai in Jombang, East Java. Canberra: ANU E-Press, 2006.

Wahid, Marzuki dkk. Pesantren Masa Depan: Wacana Pemberdayaan dan Transformasi Pesantren. Jakarta: Pustaka Hidayah, 1999.

Walinga, Muh. Hatta. "Kiyai Haji Muhammad As'ad hidup dan perjuangannya". Skripsi sarjana Fak. Adab IAIN Alauddin, Makassar, 1981.

Walzer, Michael. “The Idea of Civil Society.» Dissent (Spring), 1991: 293-304.

Zaini, Achmad. Kyai Haji Abdul Wahid Hasyim: His Contribution to Muslim Educational Reform and Indonesian Nationalism during the Twentieth Century. Yogyakarta: Indonesian Academic Society XXI, 1998. 